\title{
Pituitary-Thyroid Function in Pendred's Syndrome
}

\author{
A. GOMEZ-PAN, D. C. EVERED, R. HALL
}

\section{Patients and Methods}

The subjects studied were a sibship of nine whose mother had married twice. One of the five children of the first marriage had a goitre and three of the four from the second marriage had goitres and were deaf (see fig.). All the patients lived in County Durham which is not an iodine-deficient area.

Pendred's syndrome is reported in three siblings. All were euthyroid, with large goitres and deaf mutism and all had an unusual deposition of pigment in the retina. All had raised circulating levels of triiodothyronine $(T-3)$ and an exaggerated response of thyroid-stimulating hormone (TSH) to thyrotrophin-releasing hormone (TRH). It appears that their compensated euthyroid state was maintained by the raised $T-3$ levels. We suggest that preferential $T-3$ production is maintained by increased TSH secretion in subjects with intrathyroidal iodine deficiency secondary to thyroid organification defect.

\section{Introduction}

A combination of goitre and deafness occurring in patients living in non-iodine deficient areas is known as Pendred's syndrome, after the practitioner who referred the first two siblings with this disorder to the Newcastle Infirmary (Pendred, 1896). Characteristic features are nerve deafness, which may be present at birth or develop during early childhood, and a goitre which may become apparent in childhood or later. Subjects may be euthyroid or hypothyroid and their intelligence is usually normal. No associated clinical features have been reported. Diagnosis is facilitated by the perchlorate discharge test introduced by Morgans and Trotter (1957) which reveals the underlying defect of organification of iodide in the thyroid. In Pendred's syndrome, which is only one of a variety of thyroid organification defects, there is no deficiency of iodide peroxidase or tyrosine iodinase activity nor is there any defect at the site where the prosthetic group reacts with the enzyme (Burrow et al., 1972). It has been suggested that there may be some separate defect of the iodination mechanism, perhaps involving the formation of hydrogen peroxide. The condition is familial and in most cases inheritance appears to be on a Mendelian recessive basis.

Several euthyroid patients with Pendred's syndrome had been studied previously by one of us (R.H.). All had serum protein-bound iodine levels below normal or at the lower end of normal range. In view of this finding and of the similarity between the congenital defect of thyroid hormone formation in Pendred's syndrome and the acquired defeot of organification induced by antithyroid drugs of the carbimazole group, serum levels of triiodothyronine (T-3) were measured and other tests of pituitary-thyroid function were performed in three siblings with the syndrome. Other abnormalities were found in this family.

\footnotetext{
Department of Medicine, University of Newcastle upon Tyne, Royal Victoria Infirmary, Newcastle upon Tyne NE1 4LP A. GOMEZ-PAN, L.M.s., Research Fellow

D. C. EVERED, M.D., M.R.C.P., Wellcome Senior Research Fellow in Clinical Science

R. HALL, M.D., F.R.C.P., Professor
}

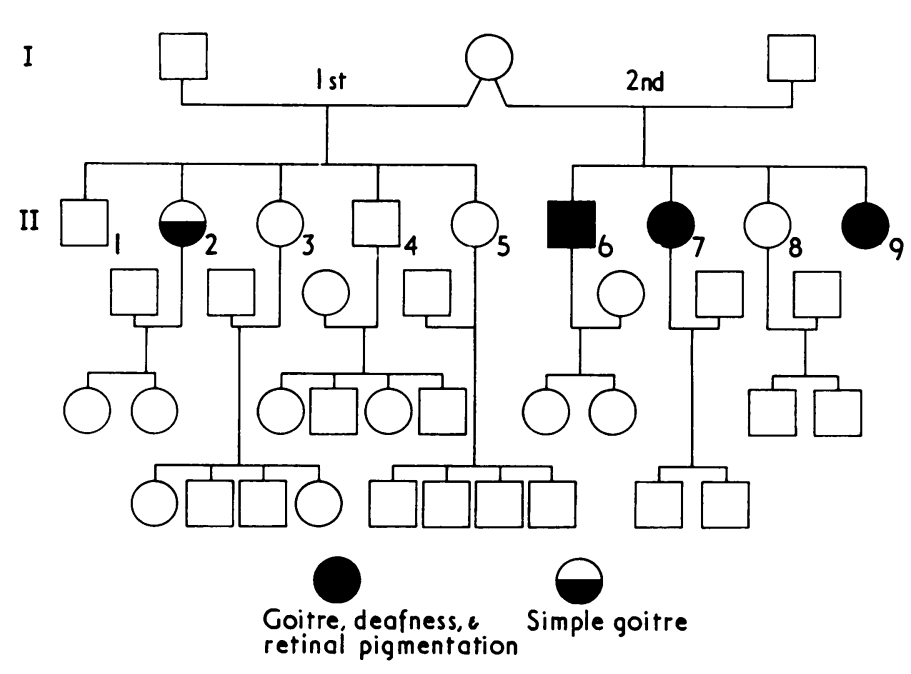

Pedigree of family.

Subject II 7.-The propositus, a 27-year-old woman, had had a goitre since childhood and had been deaf from birth. She was clinically euthyroid and was of average intelligence. Her vision was normal but her fundi showed pigmentary changes with some lature was normal.

Subject II 6.-This 31-year-old man had suffered from goitre and deafness since birth. He was euthyroid, of average intelligence, and his fundi showed pigmentary changes similar to those of the propositus but to a lesser degree.

Subject II 9.- This 22-year-old woman had a congenital goitre and deafness, was euthyroid, and had retinal changes similar to those of the propositus.

Serum P.B.I. was measured by the Technicon AutoAnalyzer and residual binding capacity of serum by the Thyopac- 3 method (Radiochemical Centre, Amersham); the free thyroxine index was calculated from these values. Serum thyroxine (T-4) was measured by the Thyopac- 4 method (Radiochemical Centre, Amersham) T-3 by radioimmunoassay of unextracted serum (Hesch and Evered, 1973), and thyroid-stimulating hormone (TSH) by a double antibody radioimmunoassay (Hall et al., 1971). Thyroid antibodies (to thyroglobulin and microsomes) were determined as previously described (Evered et al., 1973); the thyrotrophin-releasing hormone (TRH) test was performed as described by Ormston et al. (1971); and the thyroid organification process was tested by administering $600 \mathrm{mg}$ of potassium perchlorate orally one to two hours after an oral dose of $10 \mu \mathrm{Ci}$ of ${ }^{131} \mathrm{I}$, expressing the discharge as a percentage of the maximal uptake. mottling and migration of retinal pigment. The retinal vascu- 
Thyroid Function Tests in Pendred's Syndrome

\begin{tabular}{|c|c|c|c|c|c|c|c|c|c|c|}
\hline \multirow{2}{*}{ Subject No. } & \multirow{2}{*}{$\begin{array}{c}\text { Serum } \\
\text { P.B.I. } \\
(\mu \mathrm{g} / 100 \mathrm{ml})\end{array}$} & \multirow{2}{*}{$\underset{\text { Thyopac-3 }}{\text { Serum }}$} & \multirow{2}{*}{$\begin{array}{l}\text { Free } \\
\text { Thyroxine } \\
\text { Index }\end{array}$} & \multirow{2}{*}{$\begin{array}{c}\text { Serum } \\
\text { Thyroxine } \\
(\mu \mathrm{g} / 100 \mathrm{ml})\end{array}$} & \multirow{2}{*}{$\begin{array}{l}\text { Serum } \\
\text { Triiodothy- } \\
\text { ronine } \\
(\mathrm{ng} / \mathrm{m} !)\end{array}$} & \multirow{2}{*}{$\begin{array}{l}\text { Potassium } \\
\text { Perchlorate } \\
\text { Test } \\
\text { Discharge as } \\
\% \text { of Max. } \\
\text { Uptake }\end{array}$} & \multirow{2}{*}{$\begin{array}{l}\text { Circulating } \\
\text { Thyroid } \\
\text { Antibodies }\end{array}$} & \multicolumn{3}{|c|}{$\begin{array}{l}\text { TSH Released in Response to TRH } \\
\text { Test }(\mu \mathrm{U} / \mathrm{ml})\end{array}$} \\
\hline & & & & & & & & 0 mins & $20 \mathrm{mins}$ & 60 mins \\
\hline $\begin{array}{c}\text { II } 7 \\
\text { II } 6 \\
\text { II } 9 \\
\text { Mean normal values } \\
(95 \% \text { confidence limits })\end{array}$ & $\begin{array}{c}3 \cdot 2 \\
6 \cdot 2 \\
5 \cdot 8 \\
5 \cdot 7 \\
(3 \cdot 1-8 \cdot 3)\end{array}$ & $\begin{array}{c}119 \\
116 \\
126 \\
106 \\
(92-120)\end{array}$ & $\begin{array}{c}2 \cdot 7 \\
5 \cdot 3 \\
4 \cdot 6 \\
5 \cdot 3 \\
(2 \cdot 5-9 \cdot 0)\end{array}$ & $\begin{array}{c}3 \cdot 7 \\
6 \cdot 4 \\
6 \cdot 9 \\
8 \cdot 2 \\
(4 \cdot 4-12 \cdot 0)\end{array}$ & $\begin{array}{c}1.91 \\
1.98 \\
2 \cdot 14 \\
1.26 \\
(0.79-1 \cdot 73)\end{array}$ & $\begin{array}{l}50 \\
40 \\
38 \cdot 8 \\
-\end{array}$ & $\begin{array}{l}0 \\
0 \\
0 \\
0\end{array}$ & $\begin{array}{c}5.6 \\
3.0 \\
4.9 \\
(<0.5-4 \cdot 0)^{*}\end{array}$ & $\begin{array}{c}49 \\
34 \\
32 \\
(6 \cdot 5-20 \cdot 5)^{*}\end{array}$ & $\begin{array}{c}33 \cdot 5 \\
22 \cdot 0 \\
24 \cdot 5 \\
(4 \cdot 0-15 \cdot 6)^{*}\end{array}$ \\
\hline
\end{tabular}

* Normal values for men and women derived from Ormston et ul. (1971).

\section{Results}

The results of the thynoid function tests in the three affected members of the family and in controls are shown in the table. Serum T-3 was raised and the perchlorate test was positive in all the subjects. No circulating thyroid antibodies were found. Basal TSH levels were minimally raised in two subjects and the TSH response to TRH was exaggerated in all of them.

\section{Discussion}

The three siblings were clearly suffering from Pendred's syndrome. They had goitres, deaf mutism, and a thyroid organification defect indicated by the positive perchlorate discharge. All showed an unusual pattern of retinal pigmentation, an association not previously reported. They were clinically euthyroid and though the serum free thyroxine indices were in the normal range the increase in basal TSH and exaggerated response to TRH implied a suboptimal concentration of circulating thyroid hormone. The serum T-3 concentration was raised in all three subjects (but not in the unaffected relatives) and we assume that the increase was the result of increased TSH stimulation and maintained the euthyroid state. Preferential production of T-3 to maintain the euthyroid state has been reponted in subjects with endemic goitre (Kochupillai et al., 1973), after treatment with radioiodine, after pro- pylthiouracil therapy (Sterling, 1970), and in the early stages of thyroid failure associated with autoimmune thyroid disease (Evered et al., 1973). Probably an enhanced production of T-3 in these situations compensates for reduced $\mathrm{T}-4$ production in subjects with a diminished intrathyroidal iodine pool. It seems likely that a similar situation occurs in subjects with Pendred's syndrome, though the possibility of increased peripheral conversion of $T-4$ to $T-3$ has not been excluded.

This work was supported by grants from the Wellcome Trust, the Medical Research Council, and the Scientific Research Council of Spain. We acknowledge the technical help of Mr. D. Weightman and Mrs. E. Green, and the help of the Departments of Clinical Biochemistry and Medical Physics.

\section{References}

Burrow, G. N., Spaulding, S. W., Alexander, N. M., and Bower, B. (1972), Israel fournal of Medical Sciences, $8,11$.

Evered, D. C., Ormston, B. J., Smith, P. A., Hall, R., and Bird, T. (1973). British Medical fournal, 1, 657.

British Medical fournal, 1, 657.
Hall, R., Amos, J., and Ormston, B. J. (1971). British Medical fournal, 1, 582. Hesch, R. D., and Evered, D. C. (1973). British Medical fournal, 1, 582.

Kochupillai, N., et al. (1973). Lancet, 2, 1023.

Morgans, M. E., and Trotter, W. R. (1958). Lancet, 1, 607.

Ormston, B. J., Garry, R., Cryer, R. J., Besser, G. M., and Hall, R. (1971). Lancet, $2,10$.

Pendred, V. (1896). Lancet, 2, 532.

Sterling, K. (1970). Recent Progress in Hormone Research, 26, 249.

\section{PRELIMINARY COMMUNICATIONS}

\section{Heparin Prophylaxis against Fatal Postoperative Pulmonary Embolism*}

\author{
SHANTI SAGAR
}

British Medical fournal, 1974, 2, 153-154

\section{Summary}

Low-dose heparin prophylaxis against fatal pulmonary embolism has. been studied in a random and prospective trial in 300 patients over the age of $\mathbf{5 0}$ who underwent major surgery. A dose of 5,000 IU mucous heparin sodium given two hours

*Based on a paper presented at the West Midlands Surgical Society Meeting at Birmingham on 27 October 1973.

North Staffordshire Hospital Centre, Stoke-on-Trent, Stafis SHANTI SAGAR, F.R.C.S., Surgical Registrar preoperatively and for five days post operatively prevented fatal pulmonary embolism in all 156 patients so treated, whereas out of 144 patients in the unheparinized group 6 $(4.2 \%)$ died of pulmonary embolism. This difference is statistically significant. There was no increase in operative or postoperative bleeding or in the formation of wound haematomas in the heparinized group.

\section{Introduction}

Prophylactic low-dose heparinization of patients over 50 years of age lowers the incidence of postoperative deep vein thrombosis (Sharnoff and De Blasio, 1970; Kakkar et al., 1972). So far there is no evidence that prophylactic heparinization will reduce the incidence of postoperative fatal pulmonary embolism (British Medical fournal, 1973; Wessler and Thye Lin, 1973).

The factors responsible for venous thrombosis are thought to be stasis, intimal damage, and increased coagulability of the blood (Virchow, 1856; Browse, 1970). Pelvic venous pooling and intimal damage cannot be influenced with certainty, whereas the coagulability of the blood can be readily decreased. The operative period is regarded generally as the 